Cellular Physiology
and Biochemistry and Biochemistry Published online: July 11, 2016

Accepted: June 07, 2016

This article is licensed under the Creative Commons Attribution-NonCommercial-NoDerivatives 4.0 International License (CC BY-NC-ND) (http://www.karger.com/Services/OpenAccessLicense). Usage and distribution for commercial purposes as well as any distribution of modified material requires written permission.

Original Paper

\title{
Long-Term Pulmonal Therapy of Cystic Fibrosis-Patients with Amitriptyline
}

\author{
Constantin Adams ${ }^{\mathrm{a}}$ Vanya Icheva ${ }^{\mathrm{a}}$ Caroline Deppisch ${ }^{\mathrm{a}}$ Josefine Lauer $^{\mathrm{a}}$ \\ Gloria Herrmann ${ }^{\mathrm{a}}$ Ute Graepler-Mainka ${ }^{\mathrm{a}}$ Susanne Heyder ${ }^{\mathrm{a}}$ Erich Gulbins ${ }^{\mathrm{b}, \mathrm{c}}$ \\ Joachim Riethmuellera
}

aDepartment of Paediatrics, University Hospital Tuebingen, Tuebingen, ${ }^{\mathrm{b}}$ Department of Molecular

Biology, University of Duisburg-Essen, Essen, Germany; 'Department of Surgery, University of Cincinnati, Cincinnati, USA

\author{
Key Words \\ Cystic Fibrosis • Amitriptyline $•$ Ceramide $・$ CFTR
}

\begin{abstract}
Background/Aims: Several recent clinical studies revealed an accumulation of ceramide in bronchial epithelial cells of patients with cystic fibrosis (CF). Degradation of ceramide concentrations in lungs of CF patients employing the functional acid sphingomyelinase inhibitor amitriptyline revealed a benefit in lung function, weight and exacerbation rates. Methods: To test for a beneficial effect of amitriptyline in vivo, we performed two phase II randomised, double-blind, placebo-controlled studies. CF patients were treated with $25 \mathrm{mg}$ amitriptyline twice daily, i.e. a total dose of $50 \mathrm{mg} / \mathrm{d}$. After those two studies part of the patients used amitriptyline in an off-lable-use for routine treatment. These patients were observed after one, two and three years after continuous use of amitriptyline and were matched with those patients who were not treated. These patients were used as a control group. Results: After one year of treatment, forced expiratory volume in $1 \mathrm{sec}$ predicted $\left(\mathrm{FEV}_{1}\right)$ increased significantly by $7.6 \pm 7.0 \%, p=<0.001$, and weight increased by $2.1 \pm 2.3 \mathrm{~kg}, \mathrm{p}=<0.001$ in the amitriptyline population $(n=20)$, whereas $\mathrm{FEV}_{1}$ decreased significantly in the control group by $1.8 \pm 3.3 \%, p=0.010$, and weight increased by $1.1 \pm 2.7 \mathrm{~kg}, p=0.010(n=14)$. After two years of treatment, $\mathrm{FEV}_{1}$ increased significantly by $5.6 \pm 10.3 \%$, $\mathrm{p}=0.009$, and weight increased by $3.6 \pm 2.9 \mathrm{~kg}, p=<0.001$ in the amitriptyline population $(n=12)$. In contrast, $F E V_{1}$ decreased in the control group by $2.1 \pm 3.7 \%, p=0.051$ and weight increased by only $0.4 \pm 2.9 \mathrm{~kg}, p=0.31$ $(n=10)$. After three years of treatment, $F_{1}$ increased significantly by $7.7 \pm 8 \%, p=0.050$, and weight increased by $7.3 \pm 3.8 \mathrm{~kg}, p=0.016$, in the amitriptyline population $(n=5)$, whereas $\mathrm{FEV}_{1}$ decreased in the control group by $1.0 \pm 1.3 \%, p=0.075$ and weight increased by $0.4 \pm 1.5 \mathrm{~kg}$, $p=0.29(n=5)$. Conclusion: Amitriptyline significantly increases $\mathrm{FEV}_{1^{\prime}}$, reduces ceramide in lung cells and increases weight of CF patients.
\end{abstract}




\section{Cellular Physiology Cell Physiol Biochem 2016;39:565-572 \\ \begin{tabular}{l|l} 
DOI: 10.1159/000445648 & $\begin{array}{l}\text { O 2016 The Author(s). Published by S. Karger AG, Basel } \\
\text { www.karger.com/cpb }\end{array}$
\end{tabular} \\ Adams et al.: Amitriptyline in Cystic Fibrosis}

\section{Introduction}

Cystic fibrosis (CF) is the most common autosomal recessive disorder in western countries. The disease is caused by mutations in the cystic fibrosis transmembranous conductance regulator (CFTR) molecule [1-3]. The disease is characterized by chronic pulmonary inflammation, increased infection susceptibility and fibrosis [4-8]. Chronic bacterial respiratory infections especially by Ps. aeruginosa have the greatest impact on morbidity and mortality of the patients [5]. Recent animal studies offer an attractive novel possibility to treat cystic fibrosis [6]. We demonstrated in mice genetically deficient for Cftr an accumulation of ceramide in tracheal and bronchial epithelial cells [9-11]. The results were independently confirmed by several studies and, most importantly, also transferred to the human situation demonstrating accumulation of ceramide in bronchial epithelial cells of patients with cystic fibrosis [12-18]. Ceramide mediates increased death of bronchial epithelial cells resulting in a release of dead cells and finally DNA into the bronchial lumen [9].

Ceramide is generated by de novo synthesis and by hydrolysis of sphingomyelin [19]. We have previously shown that genetic or pharmaclogical inhibition of the acid sphingomyelinase that converts sphingomyelin to ceramide in lysosomes, secretory lysosomes and on the plasma membrane normalizes the increased ceramide levels in cystic fibrosis mice $[9,18]$. Pharmacological inhibition of the acid sphingomyelinase was achieved by the use of amitriptyline and other tricyclic antidepressants $[9,18]$. Previous studies demonstrated that amitriptyline and structural similar compounds functionally inhibit the acid sphingomyelinase and thereby reduce cellular ceramide in vitro and well as in vivo and that the reduction of ceramide levels in the hippocampus of stressed mice by these compounds mediates the anti-depressive effects of the drugs in vivo [20-23].

These very encouraging animal data prompted us to test for a beneficial effect of amitriptyline in CF patients. Amitriptyline is well established in treatment of patients with major depression and clinical studies are warranted to assess tolerability and efficacy of amitriptyline for treatment of CF patients. We have previously assessed the therapeutic efficacy and safety of amitriptyline in a pilot study involving $4 \mathrm{CF}$ patients treated with amitriptyline or placebo demonstrating a significant increase in lung function after 2 weeks of treatment with amitriptyline. We subsequently performed a phase IIa study for safety, proof-of-mechanism and dose-finding study involving $19 \mathrm{CF}$ patients [15] and we performed a phase IIb study on $40 \mathrm{CF}$-patients treated with $25 \mathrm{mg}$ amitriptyline twice daily. We demonstrate an increase of $\mathrm{FEV}_{1}$ in the intention-to-treat (ITT) and PP populations upon treatment of CF patients with amitriptyline for four weeks [24].

These studies revealed that amitriptyline is safe in CF patients, since only mild adverse effects were observed [15, 24]. Moreover, the per protocol (PP) analysis of these studies demonstrated an increase of the forced expiratory volume in one second $\left(\mathrm{FEV}_{1}\right)$ after treatment with amitriptyline compared to the placebo group by 4.2 and $4.9 \%$ absolute to baseline after 4 weeks of treatment suggesting an improvement of lung functions by amitriptyline.

Here we performed a case control study on 20 CF-patients treated with $25 \mathrm{mg}$ amitriptyline twice daily as an off-lable-use for one or more years after previous participation in one of these trials mentioned above, controlled by 14 patients who did not use amitriptyline for the following years.

We demonstrated a marked increase of $\mathrm{FEV}_{1}$ and body weight in the amitriptyline treatment group for one or more years. The side effects of the treatment are minor and amitriptyline is well tolerated by CF patients.

\section{Materials and Methods}

Study design

We performed in 2007 a phase IIa and in 2012 a phase IIb study in multicentric, randomised, doubleblind, placebo-controlled, cohort study designs with $59 \mathrm{CF}$ patients. 


\section{Cellular Physiology Cell Physiol Biochem 2016;39:565-572 \begin{tabular}{l|l} 
and Biochemistry Published online: July 11,2016 & $\begin{array}{l}\text { D) } 2016 \text { The Author(s). Published by S. Karger AG, Basel } \\
\text { www.karger.com/cpb }\end{array}$ \\
\hline
\end{tabular} \\ Adams et al.: Amitriptyline in Cystic Fibrosis}

A case controlstudy was initiated after these two studies were finished and part of the patients continued to take amitriptyline, which was possible in an off-lable-use. 20 patients on amitriptyline treatment could be followed up for one, two and three years and 14 patients without amitriptyline treatment.

Patients

Patients older than 14 years were included in these studies based on the following criteria: cystic fibrosis was verified; patient's weight was more than $35 \mathrm{~kg}$; $\mathrm{FEV}_{1}$ was higher than $30 \%$ and lower than 90\%; patient was pulmonary colonized with bacteria; no acute pulmonary illness was present. Patients were excluded from the study based on the following criteria: $\mathrm{FEV}_{1}$ in baseline differed more than $10 \%$ from screening visit; CRP in baseline differed more than 50\% from screening visit; glaucoma, seizures, heart insufficiency or major depression were present; intravenous antibiotic treatment was necessary in the last 4 weeks before inclusion visit; high dose steroid therapy was necessary; on/off-therapy of tobramycin was present in the last 2 weeks. During treatment period, patients were treated for 28 days.

After the follow up visit 20 out of 59 patients asked for continuing the amitriptyline treatment, which was done in an off-lable-use ( 2 x 25 mg continuously for one to three years).

\section{Outcome}

The outcome parameter $\mathrm{FEV}_{1}$ was defined as the best $\mathrm{FEV}_{1}$ measured in one year (usually done 4 times or more per year) measured by spirometry (Jaeger, Höchberg, Germany). The outcome parameter body weight was also registered 4 times or more per year. The average of the weight measurements were taken for analysis. Adverse effects (AEs) were not found during the observation period. Pulmonary exacerbation rates defined after Fuchs et al. did not differ between treatment and control group and therefore no further analysis was performed.

$\mathrm{FEV}_{1}$ and weight were compared between treatment and control group and determined one year before, just before and one, two and three years after the studies and calculated by student's t-test with significance level $\alpha=0.05$.

\section{Results}

From the 59 adolescent and adult CF patients, 20 patients received amitriptyline for one or more years and 14 patients could be analysed for one or more years without amitriptyline treatment under routine therapy conditions. The best of $\mathrm{FEV}_{1}$ measurements in one year and the average of weight measurements per year were analysed.

The demographic data of the patients (Table 1) reveal that both groups were similar with regard to gender, age, weight, lung function parameters, pancreatic sufficiency, and chronic bacterial infections.

Table 1. Demographic data and baseline characteristics in cystic fibrosis patients treated with amitriptyline or not (controls). Presented are the characteristics of all included individuals, i.e. gender, age, weight, the forced expiratory volume in the $1^{\text {st }}$ second $\left(\mathrm{FEV}_{1}\right)$, the percentage of patients with pancreas insufficiency, the amount of patients colonized with $P$. aeruginosa, $S$. aureus, multiple resistant $S$. aureus, S. maltophilia, Fungi like A. fumigatus or Candida species, E. coli and other, not further specified bacteria in the lung. alues are means \pm SD; MRSA: methicillin resistant Staphylococcus aureus

\begin{tabular}{lccc}
\hline & Amitriptyline & Controls & $p$ value \\
\hline Characteristic & $(n=20)$ & $(n=14)$ & \\
Female Gender (\%) & 9 & 4 & 0.15 \\
Age (years) a & $26.7 \pm 8.1$ & $30.1 \pm 10.3$ & 0.14 \\
Weight $(\mathrm{kg})^{*}$ & $57.0 \pm 13.4$ & $60.7 \pm 9.0$ & 0.19 \\
FEV $_{1} \%{ }^{*}$ & $61.1 \pm 16.9$ & $65.8 \pm 16.9$ & 0.21 \\
Pancreas insufficiency (\%) & 0 & 0 & n.a. \\
P. aeruginosa, non mucoid & 16 & 11 & 0.13 \\
P. aeruginosa, mucoid & 8 & 3 & 0.08 \\
St. aureus & 15 & 11 & 0.14 \\
MRSA & 1 & 0 & n.a. \\
Stenotrophomonas maltophilia & 1 & 1 & n.a. \\
Fungi (A. fumigatus, Candida spp) & 17 & 12 & 0.13 \\
E. coli & 3 & 2 & 0.19. \\
others & 3 & 3 & n.a. \\
\hline
\end{tabular}




\section{Cellular Physiology Cell Physiol Biochem 2016;39:565-572

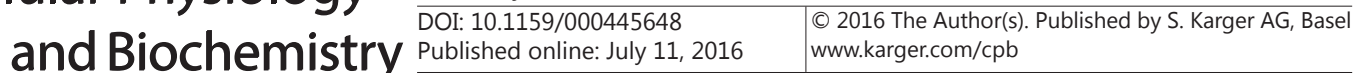 \\ Adams et al.: Amitriptyline in Cystic Fibrosis}

After one, two and three years of amitriptyline treatment lung functions of CF patients, measured as $\mathrm{FEV}_{1}$ predicted, improved significantly in the amitriptyline treatment group from a mean \pm standard deviation (SD) $61.1 \pm 16.9 \%$ to $68.7 \pm 20.3 \%$, $\mathrm{p}=0.0001$ (difference of $+7.6 \pm 7.0 \%)$ in the one year group $(n=20)$, from a mean \pm SD of $59.5 \pm 18.5 \%$ to $65.9 \pm 21.7 \%$ (diff $+6.5 \pm 7.9 \%$ ) in the first year and to $64.9 \pm 22.2 \%$ (diff $+5.6 \pm 10.3 \%$ ) in the second year, $\mathrm{p}=0.009$ in the two year group $(\mathrm{n}=12)$, and from a mean \pm SD of $56.8 \pm 23.5 \%$ to $64.3 \pm 26.1 \%$ (diff $+7.6 \pm 7.4 \%$ ) in the first year to $64.4 \pm 25.0 \%$ (diff $+7.6 \pm 7.4 \%$ ) in the second year and to $64.5 \pm 25.7 \%$ (diff $+7.7 \pm 8.0 \%$ ) in the third year, $p=0.05$ in the three year group $(n=5)$. In marked contrast, the control group $\mathrm{FEV}_{1}$ predicted consistently decreased by 1.0 to $2.6 \%$ (Table 2, Figure 1).

Table 2. FEV 1 efficacy [\% predicted] of amitriptyline in patients with cystic fibrosis at baseline, the year before, after one year, after two and three years of amitriptyline treatment compared to controls. Lung function was determined in the amitriptyline and the control group as forced expiratory volume in one second $\left(\mathrm{FEV}_{1}\right)$. The number $(\mathrm{n})$ of patients in the different groups is given. Values represent geometric means \pm standard deviations. Significant difference of $\mathrm{FEV}_{1}$ between placebo and amitriptyline-treated groups are calculated by Student's t-test. ${ }^{1,2}$ Differences between the year before to baseline and baseline to year 1 after treatment are given. ${ }^{3,4}$ Differences between baseline to year 2 after treatment and between baseline to year 3 after treatment are given. *values represent means \pm .SD. Student's t-test was used

\begin{tabular}{|c|c|c|c|c|c|c|c|}
\hline Treatment & $\begin{array}{c}\text { Number of } \\
\text { patients }\end{array}$ & $\begin{array}{c}\text { Year } \\
\text { before }\end{array}$ & $\begin{array}{c}\text { Baseline before } \\
\text { amitriptyline studies }\end{array}$ & $\begin{array}{l}\text { Year } 1 \\
\text { after }\end{array}$ & $\begin{array}{l}\text { Year } 2 \\
\text { after }\end{array}$ & $\begin{array}{l}\text { Year } 3 \\
\text { after }\end{array}$ & $p$ value \\
\hline \multirow[t]{6}{*}{ Amitriptyline } & 20 & $61.5 \pm 18.5$ & $61.1 \pm 16.9$ & $68.7 \pm 20.3$ & - & - & 0.0001 \\
\hline & & Differences ${ }^{1,2}$ & $-0.5 \pm 4.4$ & $7.6 \pm 7.0$ & - & - & 0.0008 \\
\hline & 12 & $57.3 \pm 18.6$ & $59.5 \pm 18.5$ & $65.9 \pm 21.7$ & $64.9 \pm 22.2$ & - & 0.009 \\
\hline & & Diff.s & $2.2 \pm 2.4$ & $6.5 \pm 7.9$ & $5.6 \pm 10.3$ & - & 0.075 \\
\hline & 5 & $55.3 \pm 23.8$ & $56.8 \pm 23.5$ & $64.3 \pm 26.1$ & $64.4 \pm 25.0$ & $64.5 \pm 25.7$ & 0.050 \\
\hline & & Diff..s $1,2,3,4$ & $1.5 \pm 2.3$ & $7.6 \pm 7.4$ & $7.6 \pm 7.4$ & $7.7 \pm 8.0$ & 0.07 \\
\hline \multirow[t]{6}{*}{ Controls } & 14 & $70.0 \pm 17.4$ & $65.8 \pm 24.0$ & $65.6 \pm 17.8$ & - & - & 0.010 \\
\hline & & Diff.s & $-2.6 \pm 5.1$ & $-1.8 \pm 3.3$ & - & - & 0.32 \\
\hline & 10 & $65.5 \pm 16.0$ & $63.7 \pm 17.0$ & $61.8 \pm 16.5$ & $61.6 \pm 16.9$ & - & 0.051 \\
\hline & & Diff.s & $-1.8 \pm 5.9$ & $-1.9 \pm 3.0$ & $-2.1 \pm 3.7$ & - & 0.45 \\
\hline & 5 & $64.3 \pm 20.0$ & $63.1 \pm 20.4$ & $62.1 \pm 19.1$ & $61.7 \pm 22.5$ & $62.1 \pm 21.1$ & 0.075 \\
\hline & & Diff.s & $-1.2 \pm 7.0$ & $-1.0 \pm 3.9$ & $-1.4 \pm 3.0$ & $-1.0 \pm 1.3$ & 0.48 \\
\hline
\end{tabular}
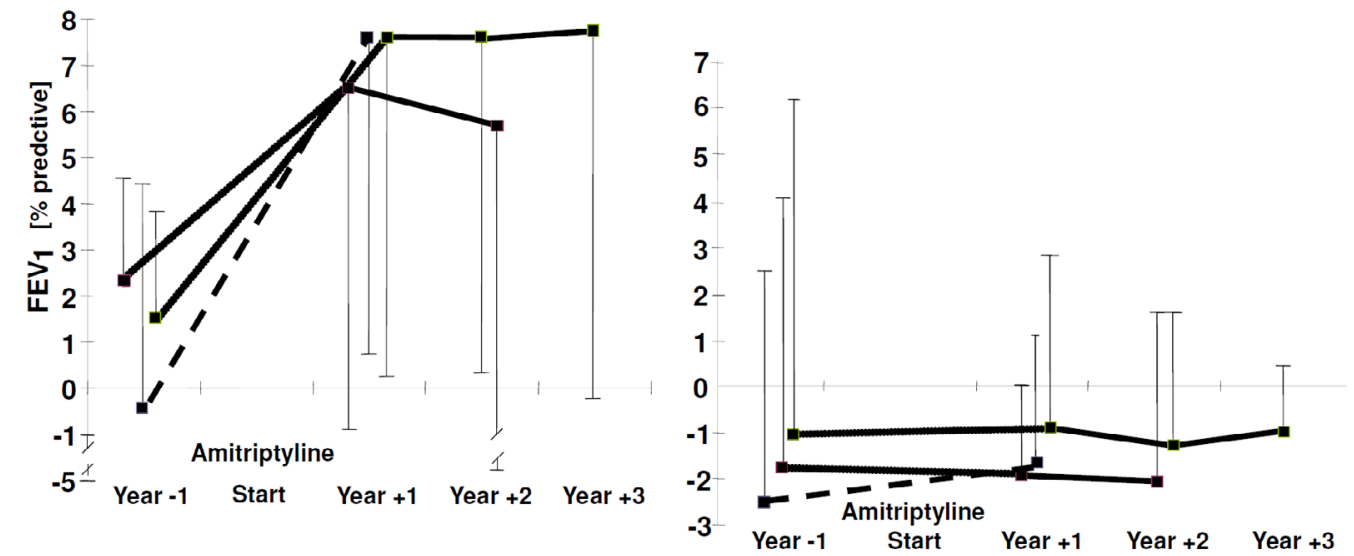

Fig. 1. Differences of $\mathrm{FEV}_{1}$ predicted in \% in long term with amitriptyline treated cystic fibrosis patients compared to controls. Left graph: 20,12 and 5 CF patients with differences of FEV 1 after 1, 2 and 3 three years of treatment with amitriptyline; means \pm SD are given. Right graph: 14,10 and 5 CF patients with differences of $\mathrm{FEV}_{1}$ after 1, 2 and 3 three years without amitriptyline treatment; means $\pm \mathrm{SD}$ are given. 
After one to three years of amitriptyline treatment weight in kg of CF patients improved significantly in the amitriptyline treatment group from a mean \pm SD of $57.0 \pm 13.4 \mathrm{~kg}$ to $59.2 \pm 13.1 \mathrm{~kg}, \mathrm{p}=0.0002$ (diff $+2.1 \pm 2.3 \mathrm{~kg}$ ) in the one year group, from a mean $\pm S D$ of $57.2 \pm 16.1 \mathrm{~kg}$ to $59.4 \pm 16.2 \mathrm{~kg}$ (diff $+2.2 \pm 1.6 \mathrm{~kg}$ ) in the first year and to $60.8 \pm 16.8 \mathrm{~kg}$ (diff $+3.6 \pm 2.9 \mathrm{~kg}$ ) in the second year, $\mathrm{p}=0.0006$, in the two year group and from a mean \pm SD of $71.5 \pm 21.2 \mathrm{~kg}$ to $74.8 \pm 20.8 \mathrm{~kg}$ (diff $+3.3 \pm 1.5 \mathrm{~kg}$ ) in the firstyear, to $76.8 \pm 21.9 \mathrm{~kg}$ (diff $+5.3 \pm 3.3 \mathrm{~kg}$ ) in the second year and to $78.8 \pm 23.0 \mathrm{~kg}$ (diff $+7.3 \pm 3.8 \mathrm{~kg}$ ) in the third year, $\mathrm{p}=0.0028$, in the three year group. Body weight of the control group weight remained unchanged by -0.1 to $1.1 \mathrm{~kg}$ (Table 3, Figure 2).

Table 3. Weight gain $[\mathrm{kg}]$ after amitriptyline in patients with cystic fibrosis at baseline, the year before, after one year, after two and three years of amitriptyline treatment compared to controls. Weight was determined in the amitriptyline and the control group. The number (n) of patients in the different groups is given. Values represent means \pm standard deviations. Significant difference of weight between placebo and amitriptyline-treated groups are calculated by Student's t-test. ${ }^{1,2}$ Differences between the year before to baseline and baseline to year 1 after treatment are given. ${ }^{3,4}$ Differences between baseline to year 2 after treatment and between baseline to year 3 after treatment are given. *values represent means \pm SD. Student's t-test was used

\begin{tabular}{|c|c|c|c|c|c|c|c|}
\hline Treatment & $\begin{array}{c}\text { Number of } \\
\text { patients }\end{array}$ & $\begin{array}{c}\text { Year } \\
\text { before }\end{array}$ & $\begin{array}{c}\text { Baseline before } \\
\text { amitriptyline studies }\end{array}$ & $\begin{array}{c}\text { Year } 1 \\
\text { after }\end{array}$ & $\begin{array}{c}\text { Year } 2 \\
\text { after }\end{array}$ & $\begin{array}{l}\text { Year } 3 \\
\text { after }\end{array}$ & $\overline{p \text { value }}$ \\
\hline \multirow{6}{*}{ Amitriptyline } & \multirow[t]{2}{*}{20} & $56.7 \pm 13.4$ & $57.0 \pm 13.4$ & $59.2 \pm 13.1$ & - & - & 0.0002 \\
\hline & & Differences ${ }^{1,2}$ & $0.3 \pm 0.8$ & $2.1 \pm 2.3$ & - & - & 0.00085 \\
\hline & \multirow[t]{2}{*}{12} & $57.0 \pm 15.8$ & $57.2 \pm 16.1$ & $59.4 \pm 16.2$ & $60.8 \pm 16.8$ & - & 0.0006 \\
\hline & & Diff.s & $0.1 \pm 0.8$ & $2.2 \pm 1.6$ & $3.6 \pm 2.9$ & & 0.0028 \\
\hline & \multirow[t]{2}{*}{5} & $71.5 \pm 20.4$ & $71.5 \pm 21.2$ & $74.8 \pm 20.8$ & $76.8 \pm 21.9$ & $78.8 \pm 23.0$ & 0.016 \\
\hline & & Diff. s $^{1,2,3,4}$ & $1.1 \pm 0.8$ & $3.3 \pm 1.5$ & $5.3 \pm 3.3$ & $7.3 \pm 3.8$ & 0.069 \\
\hline \multirow[t]{6}{*}{ Controls } & \multirow[t]{2}{*}{14} & $60.0 \pm 9.1$ & $60.7 \pm 9.0$ & $61.8 \pm 9.6$ & - & - & 0.010 \\
\hline & & Diff.s & $0.6 \pm 2.4$ & $1.1 \pm 2.7$ & & & 0.26 \\
\hline & \multirow[t]{2}{*}{10} & $57.3 \pm 4.1$ & $58.1 \pm 4.6$ & $58.8 \pm 5.2$ & $58.5 \pm 6.0$ & - & 0.31 \\
\hline & & Diff.s & $0.8 \pm 2.9$ & $0.7 \pm 2.1$ & $0.4 \pm 2.9$ & & 0.33 \\
\hline & \multirow[t]{2}{*}{5} & $58.2 \pm 5.2$ & $58.8 \pm 5.9$ & $59.3 \pm 6.6$ & $58.7 \pm 7.7$ & $59.2 \pm 5.8$ & 0.29 \\
\hline & & Diff.s & $0.6 \pm 3.1$ & $0.5 \pm 2.3$ & $-0.1 \pm 2.2$ & $0.4 \pm 1.9$ & 0.46 \\
\hline
\end{tabular}

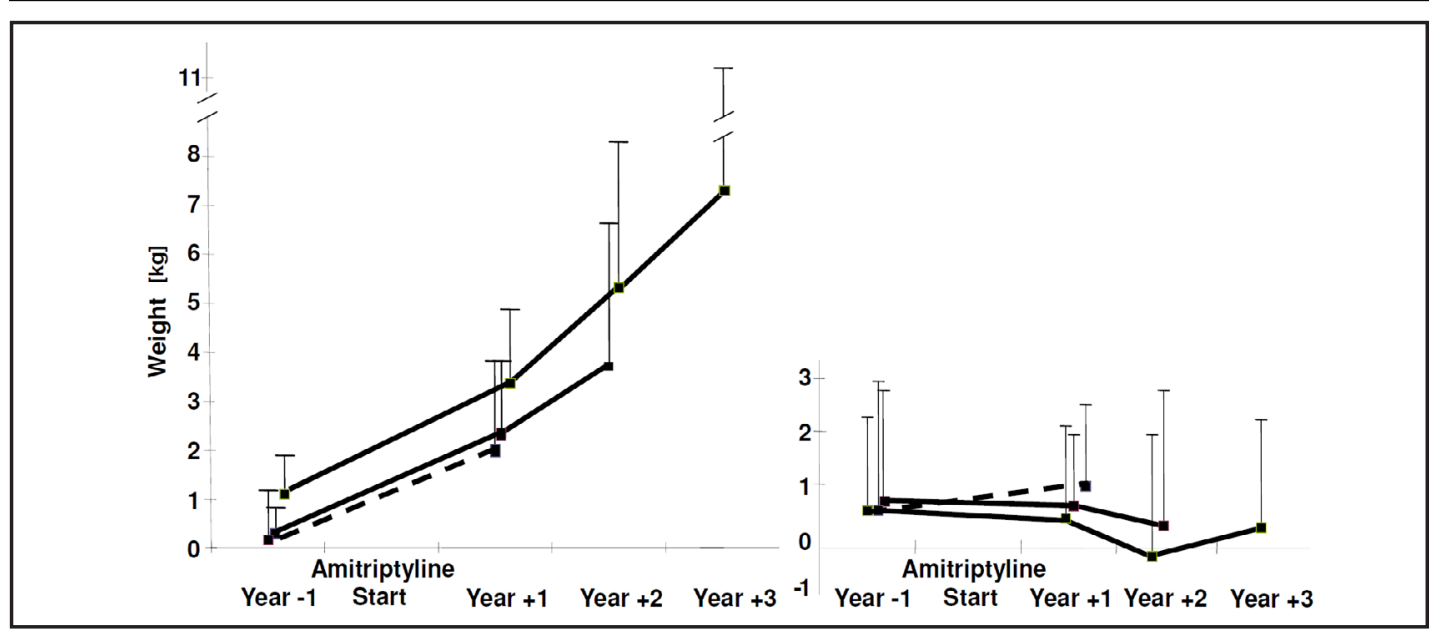

Fig. 2. Differences of weight in kg in long term with amitriptyline treated cystic fibrosis patients compared to controls. Left graph: 20,12 and 5 CF patients with differences of weight after 1, 2 and 3 three years of treatment with amitriptyline; means \pm SD are given. Right graph: 14,10 and 5 CF patients with differences of weight after 1, 2 and 3 three years without amitriptyline treatment; means \pm SD are given. 


\section{Cellular Physiology Cell Physiol Biochem 2016;39:565-572 \\ \begin{tabular}{l|l} 
and Biochemistry $\begin{array}{c}\text { DOI: 10.1159/000445648 } \\
\text { Published online: July 11,2016 }\end{array}$ & $\begin{array}{l}\text { C) } 2016 \text { The Author(s). Published by S. Karger AG, Basel } \\
\text { www.karger.com/cpb }\end{array}$
\end{tabular} \\ Adams et al.: Amitriptyline in Cystic Fibrosis}

Amitriptyline was well-received in years of treatment and no severe adverse effect, e.g. like inpatient treatment was observed in the amitriptyline-treated group. None of other typical adverse effects of amitriptyline, i.e., vertigo, arterial hypotonia, long QT syndrome, tremor, dyskinesia, obstipation, dysuria or glaukoma were observed in our observational study, very likely because of the low dose administered.

Pulmonary exacerbation rates were rare and did not differ between both groups. It should be mentioned that exacerbation rates are in general low in Europe, because of routine treatment with intravenous antibiotics.

Taken together, our data demonstrate a positive trend of amitriptyline to increase lung function and weight in long-term treatment in CF patients in contrast to the natural decrease of lung function over years in non-treated patients.

\section{Discussion}

In the present observational study, we tested whether amitriptyline improves lung functions and weight in patients with CF in a long-term setting. Since data from our phase IIa and IIb studies $[15,24]$ indicated that amitriptyline therapy using $25 \mathrm{mg}$ given twice daily is safe and increases $\mathrm{FEV}_{1}$, we were able to long-term follow patients who received amitriptyline in a routine setting as an off-lable use.

The observational study demonstrates a significant increase of lung function and weight of CF-patients over years while being treated with amitriptyline, whereas the control group declined in lung function by $1-2 \%$ per year, consistent to previous and well-known findings [25]. Although our short-term studies showed that amitriptyline reduces ceramide levels in airway epithelial cells of CF patients [15, 24], further long-term and phase III studies are required to quantify ceramide and other sphingolipid-biomarkers in sputum and respiratory epithelial cells to link a decrease of ceramide with the observed effect amitriptyline on lung functions.

Interestingly, $\mathrm{CF}$ patients also moderately gained weight in the present long-term study. This could be an effect of amitriptyline on intestinal epithelial cells and, thus, improved nutrition, but it could be also a secondary effect of the improved lung function. Further animal studies are required to define the role of ceramide and sphingolipids in the gut of CF animals and patients.

The study also demonstrates that amitriptyline, a well-established agent in treatment of major depression in adults [26], is safe at a dose of $2 \times 25 \mathrm{mg}$ /day in all CF patients when continuously given orally for years. No severe adverse drug reactions were reported, while typical AEs related to amitriptyline such as xerostomia and tiredness disappeared after a few weeks after initiation treatment.

We have previously shown that ceramide is not only harmful in the respiratory tract, but that a complete lack of ceramide release in acid sphingomyelinase-deficient mice also sensitizes these animals to bacterial infections $[9,27,28]$. This is most likely caused by a defect of a release of reactive oxygen species in cells lacking the acid sphingomyelinase [28]. However, this phenotype requires more than $90 \%$ reduction of the acid sphingomyelinase expression/activity. It is impossible to achieve such an inhibition with amitriptyline, since that drug competes with the acid sphingomyelinase for binding to the inner lysosomal membrane $[9,23]$. Therefore the maximum inhibition of the acid sphingomyelinase induced by amitriptyline is $50-60 \%$ resulting in a very safe use of the drug $[9,23]$. This partial reduction of the acid sphingomyelinase results in a normalization of the increased ceramidelevels in cystic fibrosis lungs, but not in a reduction of ceramide levels and therefore the drug does not impair the local response to P. aeruginosa [9]. Accordingly, the number of acute pulmonary exacerbations did not increase significantly in the amitriptyline group compared to controls demonstrating the safety of the applied amitriptyline dose in the CF patient study group.

Ceramide in bronchial epithelial cells has been shown to trigger cell death and thereby to mediate a release of DNA into the airways, which greatly facilitates infections with 
P. aeruginosa and also impairs the mucociliary clearance $[9,18]$. In addition, ceramide triggers, via still unknown mechanisms, the formation and release of pro-inflammatory mediators and thereby pulmonary inflammation [9]. Normalization of pulmonary ceramide concentrations by amitriptyline also normalizes these pathologies $[9,18]$. Thus, the effects of amitriptyline on FEV ${ }_{1}$ observed in the present study might be caused by a combination of normalization of epithelial cell death and mucociliary clearance and a reduction of pulmonary inflammation.

In summary, the present findings demonstrate the efficacy and safety of a treatment of $\mathrm{CF}$ patients with a low dose of amitriptyline and justify the continuation of the development of amitriptyline as a new strategy to treat CF patients. It should be pointed out that an increase of $5-8 \%$ of lung function $\left(\mathrm{FEV}_{1}\right)$ is comparable to the beneficial effects of other drugs (inhalative antibiotics, secretolytica) commonly used to treat cystic fibrosis, especially CFTR modulators and correctors like Orkambi ${ }^{\circledR}$. However, amitriptyline can be used in all CF patients regardless of the genetic defect, it is a well-known, long-term used drug with a very good safety profile at the low dose used in the study and it may also have very beneficial, systemic effects in cystic fibrosis patients, for instance in the gut.

\section{Funding}

The Phase IIa trial was supported by a financial grant from Mukoviszidose e.V., Bonn, the German Cystic Fibrosis Association and the AKF-program of the University of Tübingen, Tübingen, Germany. The Phase IIb trial was supported by a financial grant of the AKFprogram of the University of Tübingen and a local German Cystic Fibrosis Association. E.G. was supported by DFG grant GU 335/16-2.

\section{Role of the funding source}

The sponsors had no role in study design, collection, analysis, and interpretation of data, writing of the report and in the decision to submit the paper for publication.

\section{Disclosure Statement}

We declare that we have no conflict of interest.

\section{References}

1 Rommens JM, Iannuzzi MC, Kerem B, Drumm ML, Melmer G, Dean M, Rozmahel R, Cole JL, Kennedy D, Hidaka N, Zsiga M, Buchwald M, Riordan JR, Tsui LC, Collins FS: Identification of the cystic fibrosis gene: chromosome walking and jumping. Science 1989;245:1059-1065.

2 Riordan JR, Rommens JM, Kerem B, Alon N, Rozmahel R, Grzelczak Z, Zielenski J, Lok S, Plavsic N, Chou JL, Drumm ML, Iannuzzi MC, Collins FS, Tsui LC: Identification of the cystic fibrosis gene: cloning and characterization of complementary DNA. Science 1989;245:1066-1073.

3 Kerem B, Rommens JM, Buchanan JA, Markiewicz D, Cox TK, Chakravarti A, Buchwald M, Tsui LC: Identification of the cystic fibrosis gene: genetic analysis. Science 1989;245:1073-1080.

4 Boucher RC: Airway surface dehydration in CF: pathogenesis and therapy. Annu Rev Med 2007;58:157170.

5 CF Foundation, Patient Registry Annual Report 2013, Bethesda, Maryland, USA. https://www.cff. org/2013_CFF_Patient_Registry_Annual_Data_Report.pdf

6 Grothe J, Riethmüller J, Tschürtz SM, Raith M, Pynn CJ, Stoll D, Bernhard W: Plasma phosphatidylcholine alterations in cystic fibrosis patients: impaired metabolism and correlation with lung function and inflammation. Cell Physiol Biochem 2015;35:1437-1453.

7 Siegmann N, Worbs D, Effinger F, Bormann T, Gebhardt M, Ulrich M, Wermeling F, Müller-Hermelink E, Biedermann T, Tighe M, Edwards MJ, Caldwell C, Leadbetter E, Karlsson MC, Becker KA, Gulbins E, Döring G: Invariant natural killer T (iNKT) cells prevent autoimmunity, but induce pulmonary inflammation in cystic fibrosis. Cell Physiol Biochem 2014;34:56-70. 


\section{Cellular Physiology Cell Physiol Biochem 2016;39:565-572

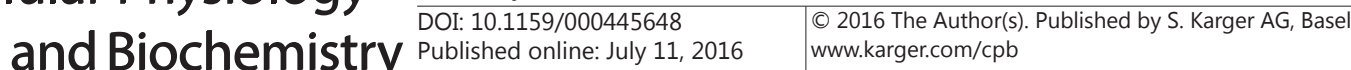 \\ Adams et al.: Amitriptyline in Cystic Fibrosis}

8 Grassmé H, Carpinteiro A, Edwards MJ, Gulbins E, Becker KA: Regulation of the inflammasome by ceramide in cystic fibrosis lungs. Cell Physiol Biochem. 2014;34:45-55.

9 Teichgräber V, Ulrich M, Endlich N, Riethmüller J, Wilker B, De Oliveira-Munding CC, van Heeckeren AM, Barr ML, von Kürthy G, Schmid KW, Weller M, Tümmler B, Lang F, Grassme H, Döring G, Gulbins E: Ceramide accumulation mediates inflammation, cell death and infection susceptibility in cystic fibrosis. Nature Med 2008;14:382-391.

10 Valdivieso ÁG, Clauzure M, Massip-Copiz M, Santa-Coloma TA: The Chloride Anion Acts as a Second Messenger in Mammalian Cells - Modifying the Expression of Specific Genes. Cell Physiol Biochem 2016;38:49-64.

11 Hao Y, Cheung CS, Yip WC, Ko WH: Nobiletin Stimulates Chloride Secretion in Human Bronchial Epithelia via a cAMP/PKA-Dependent Pathway. Cell Physiol Biochem 2015;37:306-320.

12 Brodlie M, McKean MC, Johnson GE, Gray J, Fisher AJ, Corris PA, Lordan JL, Ward C: Ceramide is increased in the lower airway epithelium of people with advanced cystic fibrosis lung disease. Am J Respir Crit Care Med 2010;182:369-375.

13 Bodas M, Min T, Mazur S, Vij N: Critical modifier role of membrane-cystic fibrosis transmembrane conductance regulator-dependent ceramide signaling in lung injury and emphysema. J Immunol 2010;186:602-613.

14 Bodas M, Min T, Vij N: Critical role of CFTR-dependent lipid rafts in cigarette smoke-induced lung epithelial injury. Am J Physiol Lung Cell Mol Physiol 2011;300:L811-820.

15 Riethmueller J, Anthonysamy J, Serra E, Schwab M, Döring G, Gulbins E: Therapeutic efficacy and safety of amitriptyline in patients with cystic fibrosis. Cell Physiol Biochem 2009;24:65-72.

16 Ulrich M, Worlitzsch D, Viglio S, Siegmann N, Iadarola P, Shute JK, Geiser M, Pier GB, Friedel G, Barr ML, Schuster A, Meyer KC, Ratjen F, Bjarnsholt T, Gulbins E, Döring G: Alveolar inflammation in cystic fibrosis. J Cyst Fibros 2010;9:217-227.

17 Pewzner-Jung Y, Tavakoli Tabazavareh S, Grassmé H, Becker KA, Japtok L, Steinmann J, Joseph T, Lang S, Tümmler B, Schuchman EH, Lentsch AB, Kleuser B, Edwards MJ, Futerman AH, Gulbins E: Sphingoid long chain bases prevent lung infection by Pseudomonas aeruginosa. EMBO Mol Med 2014;6:1205-1214.

18 Becker KA, Riethmüller J, Lüth A, Döring G, Kleuser B, Gulbins, E: Acid sphingomyelinase inhibitors normalize pulmonary ceramide and inflammation in cystic fibrosis. Am J Respir Cell Mol Biol 2010;42:716724.

19 Becker KA, Tümmler B, Gulbins E, Grassmé H: Accumulation of ceramide in the trachea and intestine of cystic fibrosis mice causes inflammation and cell death. Biochem Biophys Res Commun 2010;403:368-374.

20 Becker KA, Henry B, Ziobro R, Riethmüller J, Gulbins E: Lipids in cystic fibrosis. Expert Rev Respir Med 2011;5:527-535.

21 Hurwitz R, Ferlinz K, Sandhoff K: The tricyclic antidepressants desipramine causes proteolytic degradation of lysosomal sphingomyelinase in human fibroblasts. Biol Chem Hoppe Seyler 1994;375:447-450.

22 Kornhuber J, Tripal P, Reichel M, Terfloth L, Bleich S, Wiltfang J, Gulbins E: Identification of new functional inhibitors of acid sphingomyelinase using a structure-property-activity relation model. J Med Chem 2008;51:219-237.

23 Gulbins E, Palmada M, Reichel M, Lüth A, Böhmer C, Amato D, Müller CP, Tischbirek CH, Groemer TW, Tabatabai G, Becker KA, Tripal P, Staedtler S, Ackermann TF, van Brederode J, Alzheimer C, Weller M, Lang UE, Kleuser B, Grassmé H, Kornhuber J: Acid sphingomyelinase-ceramide system mediates effects of antidepressant drugs. Nature Med 2013;19:934-938.

24 Nährlich L, Mainz JG, Adams C, Engel C, Herrmann G, Icheva V, Lauer J, Deppisch C, Wirth A, Unger K, Graepler-Mainka U, Hector A, Heyder S, Stern M, Döring G, Gulbins E, Riethmüller J: Therapy of CF-patients with Amitriptyline and Placebo - a randomised, double-blind, placebo-controlled phase IIb multicenter, cohort-study. Cell Physiol Biochem 2013;24:65-72.

25 Kraemer R, Baldwin DN, Amman RA, Frey U, Gallati S: Progression of pulmonary hyperinflation and trapped gas associated with genetic and environmental factors in children with cystic fibrosis. Respir Res 2006; 7:138.

26 Parker AC, Pritchard P, Preston T, Smyth RL, Choonara I: Enhanced drug metabolism in young children with cystic fibrosis. Arch Dis Childhood 1997;77:239-241.

27 Grassmé H, Jendrossek V, Riehle A, von Kürthy G, Berger J, Schwarz H, Weller M, Kolesnick R, Gulbins E: Host defense against Pseudomonas aeruginosa requires ceramide-rich membrane rafts. Nature Med 2003;9:322-330.

28 Zhang Y, Li X, Carpinteiro A, Gulbins E: Acid sphingomyelinase amplifies redox signaling in Pseudomonas aeruginosa-induced macrophage apoptosis. J Immunol 2008;181:4247-4254. 